Notre Dame Law School

NDLScholarship

1995

\title{
A Maternalistic Approach to Surrogacy: Comment on Richard Epstein's Surrogacy: The Case for Full Contractual Enforcement
}

Margaret F. Brinig

Notre Dame Law School, mbrinig@nd.edu

Follow this and additional works at: https://scholarship.law.nd.edu/law_faculty_scholarship

Part of the Contracts Commons, and the Family Law Commons

\section{Recommended Citation}

Margaret F. Brinig, A Maternalistic Approach to Surrogacy: Comment on Richard Epstein's Surrogacy: The Case for Full Contractual Enforcement, 81 Va. L. Rev. 2377 (1995).

Available at: https://scholarship.law.nd.edu/law_faculty_scholarship/353

This Response or Comment is brought to you for free and open access by the Publications at NDLScholarship. It has been accepted for inclusion in Journal Articles by an authorized administrator of NDLScholarship. For more information, please contact lawdr@nd.edu. 


\title{
A MATERNALISTIC APPROACH TO SURROGACY: COMMENT ON RICHARD EPSTEIN'S SURROGACY: THE CASE FOR FULL CONTRACTUAL ENFORCEMENT
}

\author{
Margaret Friedlander Brinig*
}

$\mathrm{M}$

ANY of the other participants in this Symposium have written extensively about surrogacy. Not only have they contributed to the debate, in some instances they have framed it. In some respects, therefore, I merely thank all of them and chime in. Unlike my fellow panehsts, however, I do not think surrogacy inerits an enthusiastic, positive response.

In this Comment, I propose to restate objections to specifically enforceable surrogacy contracts from a family-law perspective as well as from the philosophical or psychological roots of family law. ${ }^{1}$ I will then reexamine the problems of surrogacy from a contractarian, law-and-eco-

* Professor of Law, George Mason University School of Law. The author wishes to thank the participants at the Conference on "New Directious in Family Law" co-sponsored by the John M. Olin Program in Law and Economics and the Virginia Law Review, as well as the generous and helpful comments made by Professors Claire Hill, Lloyd Cohen, Frank Buckley, Julie Nelson and Carl Schneider.

1 With Dean Judith Areen, I beheve that the use of the family-law paradigm rather than the contract paradigm begs the question of whether surrogacy agreements should be specifically enforced. As Areen has stated:

To place the issue in an institutional context, judges must choose whether to follow contract law or family law.... Under a contract law analysis, the issues are whether the arrangement between the parties satisfies the requirements for an enforceable contract and, if so, how the contract is to be interpreted, applied, and enforced. Under a family-law analysis, the purported contract is unenforceable . . . .

Judith Areen, Baby $M$ Reconsidered, 76 Geo. L.J. 1741, 1744-45 (1988). But see Mark Strasser, Parental Rights Terminations: On Surrogate Reasons and Surrogacy Policies, 60 Tenn. L. Rev. 135, 135 (1992) ("It is neither clear that contract law would make such agreements enforceable nor clear that family law would make such contracts void or voidable."). Certainly, once the family-law system is invoked, the critical question becomes whether the best interests of the child are served by the proposed arrangement. Areen, supra, at 1745 . See, e.g., In re Baby M, 537 A.2d 1227 (N.J. 1988) (holding that the best interests of the child justified awarding custody to the genetic father). Family law examines the decision to surrender the child far more carefully than contract law examines the decision to sell other goods or services, and is far quicker to find coercion or duress than commercial law. See, e.g., Meyers v. Georgia, 183 S.E.2d 42 (Ga. Ct. App. 1971) (holding that an adoption was not valid because of lack of consent or duress); Huebert v. Marshall, 270 N.E.2d 464 (IIl. App. Ct. 1971) (same); In re Adoption of Susko, 69 A.2d 132 (Pa. 1949) (same). 
nomics perspective, showing how these same perceived problems can be framed in this language as well. As with abortion, one's "priors," as economists call thein, predetermine judgments about surrogacy, so that what we write here probably will not change anyone's mind about whether surrogacy is good or bad. For my own part, my philosophy might fairly be characterized as an endorsement of "Inaternalism."

Like Professor Epstein, who began with the problem of distancing himself from his "powerful precommitments," I begin with soine disclaimers. I am not a person who has suffered from infertility: in fact, like many women, I have struggled through most of my adult years accommodating fecundity in my personal and professional life. ${ }^{4} \mathrm{I}$ therefore cannot claim to share the experience of the many couples who have difficulty producing genetic children. I am closely related to some such couples, and have been a colleague and close friend of others. I have heard their stories and I know how much their infertility affects their marriages. I know how the frustration of wanting a child and not being able to conceive one interferes with many other aspects of their lives. In fact, this longing will feature in my economic arguments later in this Comment.

I have also never been a surrogate. I have never struggled to feed my own children; I have never had to suffer the anguish of placing them in

Surrogacy is a powerful vehicle for teaching students about the law of adoption, including rules surrounding the timing of voluntary consent, see, e.g., Va. Code Ann. $§ 63.1-220.2$ (Michie Supp. 1995) (providing that adoption is not valid until child has reached the age of 25 days and 15 days have elapsed from the date of execution of the agreement); rules surrounding the restoration of physical custody of children, see, e.g., Webb v. Charles, 611 P.2d 562 (Ariz. Ct. App. 1980) (restoring custodial rights to biological father); Dickson v. Lascaris, 423 N.E.2d 361 (N.Y. 1981) (same); and rules surrounding the ability of mothers to withhold the identity of fathers, see, e.g., In re Karen A.B., 513 A.2d 770 (Del. 1986); Robert O. v. Russell K., 604 N.E.2d 99 (N.Y. 1992); Augusta County Dep't of Social Servs. v. Unnamed Mother, 348 S.E.2d 26 (Va. Ct. App. 1986); see also Deborah L. Forman, Unwed Fathers and Adoption: A Theoretical Analysis in Context, 72 Tex. L. Rev. 967, 1028 (1994) ("[M]ost states leave the mother's right to conceal the father's identity unfettered."). I have used Baby $M$ as a vehicle for teaching adoption law since the lower court opinion was issued, and I have discovered that Professor Carl Schneider does the same.

2 Maternalism is the feminist counterpart to paternalism. For the purpose of this Comment, maternalism denotes the mother's viewpoint, particularly including that which is deemed best for the child or children in question.

3 Richard A. Epstein, Surrogacy: The Case for Full Contractual Enforcement, 81 Va. L. Rev. 2305 (1995).

4 See, e.g., Brief for Amicus Curiae National Abortion Rights Action League, Thornburgh v. American College of Obstetricians and Gynecologists, 476 U.S. 747 (1986) (Nos. 84-495 \& 83-1379), reprinted in Lynn M. Paltrow, Amicus Brief: Richard Thornburgh v. American College of Obstetricians and Gynecologists, 9 Women's Rts. L. Rep. 3, 18 (1986) ("Most women will spend the majority of these 30 years trying not to get pregnant.") 
foster care; I have never given a child up for adoption. But I have thought about some of these questions in very concrete ways, and I have counseled women who have placed children for adoption. So, although my comments cannot have the power of an Elizabeth Kane or a Mary Beth Whitehead (famous surrogates) or a Crispina Calvert or an Elizabeth Stern (women on the receiving end of surrogacy contracts), I do not pretend to speak as a disinterested observer.

Many family-law professors have problems with commercial surrogacy. ${ }^{5}$ For a variety of reasons, inost of the academic literature written by our section of the profession condemns specific enforcement of surrogacy contracts, or at least views the agencies who promote surrogacy with great suspicion. ${ }^{6}$ Most family-law professors think of surrogacy in terms of adoption, and want to apply the fairly settled and universal law of adoption to this new area. Typically they frown on surrogacy because it involves making enforceable contracts to place children before they are born, or because it involves payment for the child either to the surrogate or to the agency matching couple and surrogate, or because it frequently allows third-party custody without investigation of the homes and health of some or all of the parties. ${ }^{7}$ Some have also been worried about the

5 There are some exceptions to prove the rule, mcluding Marjorie M. Shultz, Reproductive Technology and Intent-Based Parenthood: An Opportunity for Gender Neutrality, 1990 Wis. L. Rev. 297; see also Lori B. Andrews, Surrogate Motherhood: The Challenge for Feminists, 16 Law Med. \& Health Care 72 (1988) (arguing that allowing commercial surrogacy increases reproductive freedom); Lori B. Andrews \& Lisa Douglass, Alternative Reproduction, 65 S. Cal. L. Rev. 623 (1991) (advocating surrogacy as an alternative reproductive strategy); Jane $M$. Cohen, Legal Claims of Coercive and Exploitative Agreement: Introducing Coercion-Feel, 94 APA Newsl. 99 (1994) (apparently changing her position from that expressed in Jane M. Cohen, Posnerism, Pluralism, Pessimism, 67 B.U. L. Rev. 105 (1987) [hereinafter Cohen, Posnerism], as she writes that surrogate mothers are making these choices from a mixture of reasons, including some altruistic ones).

6 See, e.g., Martha A. Field, Surrogate Motherhood (1988); Areen, supra note 1; Katharine T. Bartlett, Re-Expressing Parenthood, 98 Yale L.J. 293 (1988); Carl E. Schneider, Surrogate Motherhood from the Perspective of Family Law, 13 Harv. J.L. \& Pub. Pol'y 125 (1990); Strasser, supra note 1; Walter J. Wadlington, Baby M: Catalyst for Family Law Reform?, 5 J. Contemp. Health L. \& Pol'y 1 (1989); Barbara B. Woodhouse, Hatching the Egg: A Child-Centered Perspective on Parents' Rights, 14 Cardozo L. Rev. 1747 (1993).

7 As a kind of aside to an aside, because I was concerned about Professor Epstein's statements regarding the "senseless and intrusive inquiries that social workers often make in adoption cases," Epstein, supra note 3, at 2307, I telephoned two local public adoption agencies. In one county, the adoption social worker pointed out that the majority of her county's adoptions were undertaken by foster families, and that the preadoptive screening in all cases involved checking whether the prospective adoptive families were on criminal probation, had previous "founded" child abuse complaints, had criminal records involving 
effect of surrogacy on the adoption of "hard-to-place" children. ${ }^{8}$

On a philosophical level, many feminist family-law scholars fear that surrogacy will give men another way to exploit women because of their reproductive capacity. ${ }^{9}$ They fear for surrogates, and are concerned that surrogates may be drawn from classes of women who have historically been exploited. ${ }^{10}$ They worry that both the women and children in surrogacy arrangements are being "commodified."11

child abuse, active addiction to drugs or alcohol, or unstable marital relationships. Telephone Interview with Patricia Clark, Fairfax County Department of Human Resources (Feb. 17, 1995). None of these concerus seems particularly "senseless" or "intrusive."

8 The effects upon the "secondary market" of hard-to-place children are thoughtfully discussed in Ronald A. Cass, Coping with Life, Law, and Markets: A Comment on Posner and the Law-and-Economics Debate, 67 B.U. L. Rev. 73, 75-76, 81-82 (1987); see also Cohen, Posnerism, supra note 5, at 169 (arguing that surrogate babies "fill the booties of the hard-to-place"); J. Robert S. Prichard, A Market for Babies?, 34 U. Toronto L.J. 341, 348 (1984) (observing that "good' babies may drive out the 'bad' "). One answer to this problem is that there is no reason why infertile couples should have to shoulder the whole cost of society's burden of disabled or older children. See Richard A. Posner, The Ethics and Economics of Enforcing Contracts of Surrogate Motherhood, 5 J. Contemp. Health L. \& Pol'y 21, 24 (1989) [hereinafter Posner, Ethics and Economics]; Richard A. Posner, The Regulation of the Market in Adoptions, 67 B.U. L. Rev. 59, 65 (1987).

9 See, e.g., Katherine B. Lieber, Selling the Womb: Can the Feminist Critique of Surrogacy Be Answered?, 68 Ind. L.J. 205, 211 (1992) (“[M]ost feminist writers see surrogacy as a form of slavery or prostitution in which the surrogate is exploited through the enticements of money, the social expectation of self-sacrifice, or both."); Wanda A. Wiegers, Economic Analysis of Law and 'Private Ordering': A Feminist Critique, 42 U. Toronto L.J. 170, 193 (1992) ("[M]en have never been expected to adhere to a morality of self-sacrifice simply on account of their gender. For some women, by contrast, selfsacrifice or self-denial remains a 'way of life' and a 'consistent duty.' "); Norma J. Wikler, Society's Response to the New Reproductive Technologies: The Feminist Perspectives, 59 S. Cal. L. Rev. 1043, 1049 (1986) (observing that some feminists believe surrogacy is a form of oppression and that the choice for a woinan to become a surrogate "may result in a loss of choice in the long run"). Professor Epstein responds to these suggestions by saymg that "[t]he process of contracting always requires a surrender of some portion of autonomy, but only in exchange for things that are thought to be more valuable." Epstein, supra note 3, at 2335 .

10 See, e.g., Joan Mahoney, An Essay on Surrogacy and Feminist Thought, 16 Law Med. \& Health Care 81,81 (1988) (noting that the rate of pay for surrogates is just over $\$ 1.54$ per hour based on the going rate of $\$ 10,000$ per pregnancy). Professor Epstein calls these concerns "soft externalities," and implies that such concerns might be largely restricted to "some academic feminists and their supporters." Epstein, supra note 3, at 2323-24.

11 Margaret Jane Radin argues that some things should be permitted to be given as gifts but not sold, and should therefore be placed outside the narketplace but not outside the realm of social intercourse. See Margaret J. Radin, Market-Inalienability, 100 Harv. L. Rev. 1849, 1853 (1987). Market-inalienable things are those that are important to personhood. See id. at 1903 . This concept would include one's politics, work, religion, family, love, sexuality, friendships, altruism, experiences, wisdom, moral commitments, 
Froin a psychological standpoint; writers express their concern that surrogates, particularly those who have not yet gone through childbirth, cannot know in advance how difficult it will be to give the child up. ${ }^{12}$ Although the overwhelming number of surrogates have not tried to keep the children, and an even smaller number have litigated the issue, their regret and loss will continue. A number of articles also mention the psychological harm to the child born of the surrogate arrangement, who feels all the msecurity of any adopted child, but also, at least currently, knows some celebrity or at least distinction because of the arrangement. ${ }^{13} \mathrm{~A}$ few pieces also mention potential problems for the other children of the surrogate, ${ }^{14}$ a theme I will take up next.

The themes I would like to expand upon for a moinent, with the lawand-economics analysis to follow, involve problems for the surrogate in turning over the child, the concern for the surrogate's other children, and the potential for exploitation of both surrogate and intended parents by placing agencies. ${ }^{15}$ I conclude that although, as a policy matter, I do not feel that surrogacy ought to be legally proscribed, I do not endorse specific enforcenent of such contracts. ${ }^{16}$

character, and personal attributes, all of which are integral to the self. Cass Sunstein has likewise criticized the underlying assumptions of "markets" for babies:

Certainly the desire of infertile couples for children would be better satisfied through a market system. But part of the objection to free markets in babies is not quite engaged by Judge Posner. Instead the objection is that a system of purchase and sale would value children in the wrong way. This system would treat human beings as commodities, a view that is itself wrong ....

Cass R. Sunstein, Incommensurability and Valuation in Law, 92 Mich. L. Rev. 779, 850 (1994); see also Mahoney, supra note 10, at 82 ("Either [form of surrogacy] would seem to result in the 'commodification' of babies."). Perhaps society is channelling couples away from the institution, as Carl Schneider suggests. See Schneider, supra note 6, at 130; see also Elizabeth S. Scott, Pluralism, Parental Preference, and Child Custody, $80 \mathrm{Cal}$. L. Rev. $615,667-69$ (1992) (noting the power of informal social norms in regulating behavior).

12 See sources cited in note 34 , infra.

13 See sources cited in note 55 , infra.

14 See sources cited in note 27 , infra.

15 Interestingly, these parallel the "three types of objections" Professor Epstein says might "be plausibly offered to counteract the case for full contractual enforcement": defects in the bargaining process, adverse external effects on third parties, and questions of coordination, freeriding, and holdout. See Epstein, supra note 3, at 2309. He concludes that the potential problems are not sufficient to overcome the mutual gains froin trade. See id. at 2341.

16 Part of iny hesitation comes from my concern that courts in child-related cases state that they are acting in the child's best interest, but frequently seem to be acting in the interests of the parents. See Margaret F. Brinig, The Effect of Transactions Costs on the Market for Babies, 18 Seton Hall Legis. J. 553, 555 \& n.15 (1994); see also Woodhouse, supra note 6 , at 1855 (arguing that courts traditionally adopt "adult-centric" perspectives which iguore the child's experiences and interests); Bartlett, supra note 6, at 293-94 
Both what pushes some couples towards surrogacy and what makes observers nervous can be explained on simple biological terms. ${ }^{17}$ As Professor Epstein has noted elsewhere, we are driven by our genes to reproduce, and, more controversially, to behave in ways that will allow each succeeding generation to also be fruitful and multiply. ${ }^{18}$ Infertile couples are tormented in part because of this unsatisfied and fundainental need. ${ }^{19}$ They choose surrogacy over adoption because they wish to have at least some of their own genetic code rephicated in another human being. ${ }^{20}$ Surrogate mothers are also affected by their biology. They may

(maintaining that the law governing custody disputes encourages an undesirable view of parenthood grounded in notions of exchange and individual rights).

17 Judge Posner has criticized feminists for relying upon biology in their critiques of surrogacy although "they reject the 'privileging' of biological over social categories" in the context of abortion. Richard A. Posner, Sex and Reason 420 (1992); see also Andrews, supra note 5 , at 72 (arguing that feminist rationales justifying governmental intrusion into surrogacy "may come back to haunt feminists in other areas of procreative policy and family law").

18 See Richard A. Epstein, The Varieties of Self-Interest, 8 Soc. Phil. \& Pol'y 102 (1990); accord Matt Ridley, The Red Queen: Sex and the Evolution of Human Nature (1994); Robert Wright, The Moral Animal: The New Science of Evolutionary Psychology 35-36 (1994); Michael J. Trebilcock \& Rosemin Keshvani, The Role of Private Ordering in Family Law: A Law and Economics Perspective, 41 U. Toronto LJ. 533, 572 (1991).

19 See Forman, supra note 1, at 995 ("The deep pain of infertility experienced by men and women unable to have children, and the thriving infertility business that has developed to assist them, attest to the profound importance of the genetic tie for men and woinen alike.") (citations omitted); see also Barbara K. Rothman, Recreating Motherhood: Ideology and Technology in a Patriarchal Society 74-81 (1989) (characterizing surrogacy as a response to the desire of adults to own children). Noel P. Keane states that he began his work as a surrogacy broker "because of a very strong and straightforward bias. I believe that children fulfill one's self in a way that nothing else can ever equal." Noel P. Keane, The Surrogate Mother 23 (1981). "Maybe it's egotistical," Keane quotes one of his first clients as saying, "but I want my own child. Adoption leaves me cold. I guess for some women, as long as they have a child, it's fine. But for me, it's like if I see my child do something, I need to know that he's really mine." Id. at 29-30.

Martha Field has asked whether this is a healthy reason for wishing to have a child. See Field, supra note 6, at 50. But see Strasser, supra note 1, at 137 ("There is nothing wrong with a couple's wanting to raise a child genetically related to at least one of them ...."). I am reminded of the Russian folktale, "The Little Daughter of the Snow," in which a couple desired a child primarily to be like the other couples in their village and were unable to put her needs before their own. The more familiar legendary cases are those of Rumpelstiltskin, to whom a young girl promised her firstborn (prior to conception) to save her own life, and Rapunzel, who was traded to an old witch for a type of lettuce. One might wonder whether these are the stories that we-as a matter of law, if not of literature-should teach our children.

20 For example, William Stern, the father in the Baby $M$ case, wanted to have a child that was biologically his because the other members of his family had been killed in the Holocaust. See In re Baby M, 537 A.2d 1227, 1235 (N.J. 1988); see also Posner, Ethics and 
desire other genetic children that they cannot afford to keep in their own families, so they are attracted to surrogacy. They inay simply enjoy being pregnant and the powerful feeling of creation that comes with giving birth. ${ }^{21}$ But the dark side of these good feelings is that women are not programmed to have children and then part with them.22 A contract made beforehand, even though it may make the rational part of the placement easier, cannot affect these biological drives. ${ }^{23}$ An ad cautions us "Never mess with Mother Nature." Surrogacy contracts, by definition,

Economics, supra note 8 , at 22 ("People . . . desire genetic continuity, and surrogacy enables the man (although not his wife) to satisfy this desire.").

21 See Andrews \& Douglass, supra note 5, at 674. Professor Epstein notes the mixed motivations when he writes "[s]ome money is accepted by a surrogate who empathizes with the plight of the married couple with whom she has contracted." Epstein, supra note 3, at 2319.

22 See, e.g., Bartlett, supra note 6, at 333 ("Within custody law, there is a strong ideology that through pregnancy and childbirth an enduring bond develops between mother and child which cannot easily be broken. This mystical bond is perceived of as inevitable and more powerful than any woman can realize in advance."); Maurice M. Suh, Surrogate Motherhood: An Argument for Denial of Specific Performance, 22 Colum. J.L. \& Soc. Probs. 357, 362-69 (1989) (arguing that the bonding interests of the birth mother, which have been demonstrated by research, should prevent specific performance unless consent is given after the child's birth). But see Forman, supra note 1, at 985 ("Studies challenge the notion that 'the prenatal bond is a universal concomitant of pregnancy' or 'an immutable biological imperative." ").

Saying that consent cannot be given until after the child's birth is paternahistic, or, as I prefer it in this context (since men cannot ever know the women's problem), maternalistic. Nevertheless, arguing that consent should not be valid for some time period is a type of "hands-tying" that I feel is justified in this case. For similar arguments in other contexts, see Jon Elster, Ulysses and the Sirens: Studies in Rationality and Irrationality (1979); Thomas C. Schelling, Choice and Consequence 77-78 (1984); Anthony T. Kronman, Contract Law and the State of Nature, 1 J.L. Econ. \& Organization 5, 18-20 (1985). Although I question decisions in the case where a pregnancy is intended to go to term, my analysis does not discount or discredit the right of privacy guaranteed by the abortion cases.

${ }^{23}$ As an American report on surrogacy noted, "mater est quam gestatio demonstrat." (The mother is demonstrated by gestation.) Office of Technology Assessment, U.S. Congress, Infertility: Medical and Social Choices 282 (1988); see also Bartlett, supra note 6, at 322 ("Mothers have a kind of automatic responsibility for their children."). Perhaps this fact is a reason why fathers do not love children as unconditionally as mothers, but need some sort of proof (usually born out of interaction with the child) that the child is theirs. David Hnme, for example, argued that because the man would have to support the child, and because his love would not be as automatic as his wife's without certain knowledge of fatherhood, women must of necessity be chaste and discreet. See David Hume, A Treatise of Hnman Nature 570-73 (L.A. Selby-Bigge ed., Oxford, Clarendon Press 1888) (1739) (arguing that women should be more severely punished for adultery to guarantee the certainty of paternity). More often, the feelings of responsibility come when the father establishes a relationship with the child. The Supreme Court has recognized the siguificance of the parent-child relationship: 
do. This does not make them morally wrong, it just makes them problematic. The regret that such a placement causes does not pass away. ${ }^{24}$ It is large, probably larger than the $\$ 10,000$ that a typical surrogate receives. And I wonder whether it can be anticipated beforehand. ${ }^{25}$

If the surrogate has other children and perhaps therefore more information, problems for the surrogate's other children may surface. ${ }^{26}$ How do they know that Mommy will not decide to give them away if she needs money or if she decides that another couple needs them more than she ${ }^{27}$

The significance of the biological connection is that it offers the natural father an opportunity that no other male possesses to develop a relationship with his offspring. If he grasps that opportunity and accepts some measure of responsibility for the child's future, he may enjoy the blessings of the parent-child relationship and make uniquely valuable contributions to the child's development.

Lehr v. Robertson, 463 U.S. 248, 262 (1983).

24 See, e.g., Eva Y. Deykin, Lee Campbell \& Patricia Patti, The Postadoption Experience of Surrendering Parents, 54 Am. J. Orthopsychiatry 271, 280 (1984) ("Since grief over a surrendered child appears to remain undimmed with time, present knowledge of the dynamics of mourning may only partially apply to this situation."); Edward $\mathrm{K}$. Rynearson, Relinquishment and Its Maternal Complications: A Preliminary Study, 139 Am. J. Psychiatry 338, 338-39 (1982).

25 Professor Andrews argues that "with volumes of publicity given to the plight of Mary Beth Whitehead, all potential surrogates are now aware of the possibility that they may later regret their decisions." Andrews, supra note 5, at 74. Another commentator asserted that, even for a mother who has had children, the bonding with each child during pregnancy is unique. See Suh, supra note 22 , at 379 . I would state it another way. As mothers know - as my mother even told me-once a child is born, you forget, to a certain extent, about the problems of pregnancy and the pain of childbirth. If it were not so as a biological matter, not enough children would be born to keep humanity from becoming extinct. You know this in your rational mind, but you cannot remember it in your subconscious. So perliaps regardless of intellectual knowledge, you could not know beforehand how difficult the parting will be.

26 The surrogate is not making her decisions in a vacuum, any more than the pregnant woman does. Cf. Roe v. Wade, 410 U.S. 113, 159 (1973) ("The pregnant woman cannot be isolated in her privacy.").

27 See, e.g., Anita L. Allen, Privacy, Surrogacy, and the Baby $M$ Case, 76 Geo. L.J. 1759, 1763 (1988) ("All children may be burdened by special fears and insecurities in a society where their parents may obtain money for family necessaries by giving away newborn siblings."); Schneider, supra note 6, at 125-26 ("The siblings of children given up by surrogate mothers may fear for their own status in the family."). This problem, in the context of the adoption market, has been sensitively addressed by Jane Colien. See Colien, Posnerism, supra note 5, at 152-53. Lori Andrews discusses the issue in this way:

Baby-selling is prohibited in our society, in part because children need a secure family life and should not have to worry that they will be sold and wrenched from their existing family. Surrogacy is distinguishable from baby-selling since the resulting child is never in a state of insecurity. . . . There is thus no psychological stress to that child or to any other existing child that he or she may someday be sold. Andrews, supra note 5, at 77. She continues that "[i]f the children are told from the beginning that this is the contracting couple's child-not a part of their own family-they will 
Again, I have seen this fear in my own children. A few weeks ago, we had to give away a dog that we had for several years. None of the children had paid the dog any attention (let alone taken care of it) since he was a puppy. The dog was the butt of numerous family jokes, and bore a series of derogatory nicknames largely derived from the fact that he was incapable of being housetrained. Nonetheless, my three-year-old son Brian has been very insecure since then. He constantly asks about the $\mathrm{dog}$, and is reassured that the dog is with a family that really loves him. Brian has reverted to needing extensive cuddles at bedtime, the hight left on, and a "security blanket." As far as I know, nothing has changed in his life except for Twinkle's departure.

If the dog example does not move you, I can tell you another story. A professional woman was undergoing a problem pregnancy. She was a divorced mother with small children, and the natural father of the expected baby did not wish to have anything to do with the child; he suggested that she either have an abortion or place the baby for adoption. The woman would not consider abortion for religious reasons, but sought counseling about adoption. The respected child psychiatrist she consulted said that placing the new child for adoption would be a disaster as far as her existing children were concerned, even if they knew "from the beginning" that the child would never be a member of their family. I worry about the surrogate's children.

realize that they themselves are not in danger of being relinquished," id., and she relates the testimony of one surrogate who told her child that she entered into the contract to help the other couple who wanted a child to love as much as he was loved. Id. In her Comment included in this Symposium, Andrews mentions similar expressions by other surrogates. See Lori B. Andrews, Beyond Doctrinal Boundaries: A Legal Framework for Surrogate Motherhood, 81 Va. L. Rev. 2343, 2349-50 (1995). However, I question the scientific reliability of a study including verbal interviews of only 80 surrogates, who self-selected by volunteering. Children interviewed with their mothers present may not have given accurate and unbiased reports. My own work with children, empirical as well as anecdotal, indicates that they cannot make this kind of distinction, particularly before they reach the "age of reason." See Margaret F. Brinig, Why Can't a Woman Be More Like A Man? (1994) (observing that children before puberty are more risk averse, more selfish, and have a much higher discount rate than do adults).

Elizabeth Kane, the first legal surrogate in the United States, testified against surrogacy before Congress:

Today I am faced with a broken family. The only thing that I have taught my children is that money can buy anything....

One thing my family will never be able to buy back are the memories that we have lost of my son [born of a surrogacy arrangement] . . . I have robbed my children and my parents of a relationship with their relative, and I am not proud of that. Surrogacy Arrangements Act of 1987: Hearings on H.R. 2433 Before the Subcomm. on Transportation, Tourism, and Hazardous Materials of the House Comm. on Energy and Commerce, 100th Cong., 1st Sess. 35 (1987) (testimony of Elizabeth Kane). 
My final concern involves the placing agency. Like real estate agents who get paid by commission whether or not the closing ever takes place, ${ }^{28}$ placing agencies get compensated by the infertile couple upon signing the surrogacy contract. ${ }^{29}$ They may not ensure that the surrogates are adequately investigated or counseled. They may not do extensive checking about the infertile couple, either. From a practical viewpoint, they are dealing with very vulnerable people on both ends of the contract, and they may encourage "matches" with unsuitable players. What is more, I do not see that they are necessary. As long as surrogacy is legal, there is nothing keeping the infertile couples, who are already very organized as groups, from creating a "clearinghouse" that, in effect, advertises their desires to find surrogates. There are already similar ads for private placement adoptions in California. Once the couple and potential surrogate have identified each other, they are already capable of contracting for home visiting or counseling by social service agencies. Since an adoption by the genetic father's wife is the desired outcome, social services will probably be involved anyway.

Now let us reconsider these three primary objections: regret by the surrogate, hardship on the surrogate's children, and exploitation by forprofit placing agencies. In economic terms, the problems involved, all of which affect the enforceability of contracts, ${ }^{30}$ are called incomplete information, substantial negative externalities, and rent-seeking.

28 In the surrogacy contract, as in the sale of real estate, the agent has a powerful incentive to close the "sale" and earn his commission, without regard to the best interests of the parties. Consider the situation posed by Allen v. Lindstrom, 379 S.E.2d 450 (Va.), cert. denied, 493 U.S. 849 (1989), where the real estate agent ended up with two contracts for the purchase of the same property. Although children born of a surrogacy agreement may not be "property," that subtle distinction could be lost on commercial agents, with disastrous results.

${ }^{29}$ See, e.g., In re Baby M, 537 A.2d 1227, 1271 app. B (N.J. 1988); see also Areen, supra note 1, at 1755 ("The one party that did take account of human sentiment was the Infertility Center, and it insulated itself against a change of feeling 'with a calculation so cold as to embarrass a social order that licenses as a service works hike these.' ") (citations omitted). Existing surrogacy statutes in New Hampshire and Virginia make people inducing any party to enter into a surrogacy contract guilty of a misdemeanor. See, e.g., N.H. Rev. Stat. Ann. \$\$ 168-B:16(IV), 168-B:30(II) (Supp. 1994); Va. Code Ann. § 20-165 (Michie Supp. 1994). Virginia also makes the broker civilly liable to the surrogate and intended parents for up to three times the amount charged by the broker. Va. Code Ann. $\S 20-165(B)$ (Michie Supp. 1994).

30 It is important to realize that specific performance is an unusual remedy. It frequently is not allowed for personal service contracts. See, e.g., Allen, supra note 27, at 1768. Professor Andrews, however, argues that the personal service aspect ends at the child's birth, so that enforcement of the provision providing for the father's custody is "like the enforcement of a court order on custody." Andrews, supra note 5, at 79 n.6. Although I will discuss the problems of enforcing the contract during pregnancy, I would hike to point 
Economics, and particularly the "new institutional" economics, rests on an informational foundation. At its core, price theory depends upon coinplete and instantaneous transmission of the qualities and prices of relevant goods. Rational consumers and producers capably process this vast stream of information. The law and economics of contracts floats upon this informational sea, selecting its terms and the degree of specificity where transaction costs increase beyond the incremental value gained by the next good or the next term. ${ }^{31}$

Contracting proves efficient regardless of the allocation of property rights so long as these transaction costs reinain low. But there are limits to contract even in the law-and-economics world. Soine contracts are not allowed for moral or other societal reasons. Some become voidable (are less than perfect) because the parties did not have enough information ex ante to make rational, efficient choices. ${ }^{32}$

out that parents, unlike courts, cannot make enforceable agreements concerning their child's custody. See infra note 54.

As Professor Epstein notes, lack of specific enforcement will probably doom the majority of surrogate arrangements. See Epstein, supra note 3, at 2334-40. If the contract cannot be specifically enforced, the only remedy for the surrogate's breach is money damages. Since almost by definition the surrogate is struggling financially, if she is not entirely judgment-proof, this remedy, including a bond, is illusory. The only other possibility is "surrogacy insurance." Perhaps this will be a growth industry; I think not. Other remedies suggested by Anthony Kronman are only feasible where there is at least a close relationship between the surrogate and the couple. See Kronman, supra note 22 (considering various means of enforcing promises among private parties). For example, the idea of union, or creating a close emotional bond to ensure performance, might succeed if the parties are already blood relatives, as was true in a recent Canadian case. See Arthur Serratelli, Note, Surrogate Motherhood Contracts: Should the British or Canadian Model Fill the U.S. Legislative Vacuum?, 26 Geo. Wash. J. Int'l L. \& Econ. 633, 635 (1993) (citing Robert Walker, Woman to Bear Child For Sister, Calgary Herald, Sept. 12, 1991, at A1); see also Andrews \& Douglass, supra note 5, at 672 (citing Juliette Zipper \& Selma Sevenhuijsen, Surrogacy: Feminist Notions of Motherhood Reconsidered, in Reproductive Technologies: Gender, Motherhood and Medicine 119, 128 (Michelle Stanworth ed., 1987) (documenting the case of a woman, whose twin sister was unable to have a child, who was artificially inseminated by her brother-in-law and relinquished the child to the couple after birth). Hostage-taking (removing the other children of the surrogate) would clearly be even more reprehensible than the worst view of the practice itself.

31 What I mean to suggest is that we continue to search until the point at which we do not expect that any improvement over the current state affairs is worth more searching. See George Stigler, The Economics of Information, 69 J. Pol. Econ. 213 (1961).

32 See, e.g., Posner, Ethics and Economics, supra note 8, at 24-25 ("Information costs provide a traditional reason for doubting whether a particular contract is actually valuemaximizing ex ante. . . . To put this differently, the tendency in economics to evaluate welfare on an ex ante rather than ex post basis depends on an assumption that expectations are not systematically biased."). Posner concludes his analysis by stating that "[a] mature 
My argument here is that surrogacy contracts are suboptimal because the surrogate cannot ex ante have perfect, or even minimally adequate, information. It is not, then, her ex post regret that drives the analysis. ${ }^{33}$ It is that she cannot have predicted accurately what the situation will be at closing time. She cannot have gauged precisely the longterm effects of what she promised before conception. ${ }^{34}$ Specific enforcement of the terms of the surrogacy contract is, therefore, inappropriate. Even in the case of the marriage contract, which society positively favors, ${ }^{35}$ specific

woman who has borne children should be able to estimate the psychic cost to her of giving up her next baby." Id. at 25 . The expectations are therefore not systematically biased.

33 The fact that a party to a contract is disappointed by the way things turn out is unfortunate, but does not relieve her of her duty to perform. See, e.g., Peter H. Schuck, Some Reflections on the Baby $M$ Case, 76 Geo. L.J. 1793, 1799 (1988) ("The risk of subsequent regret is the price we pay for our commitment to personal autonomy and responsibility in the face of uncertainty."). For the application of this principle to general commercial contracts, see Eastern Air Lines v. Gulf Oil Corp., 415 F. Supp. 429 (S.D. Fla. 1975). Compare Richard A. Epstein, Holdouts, Externalities, and the Single Owner: One More Salute to Ronald Coase, 36 J.L. \& Econ. 553, 557-58 (1993) ("It will therefore be a frequent occurrence that the ideal set of rules, measured from the ex ante perspective, will often produce a set of outcomes that will be regretted by the participants to the transactions ex post."). However, there are some exceptions to this general rule. For a discussion of the distinction between disappointment and regret, see Anthony T. Kronman, Paternalism and the Law of Contracts, 92 Yale L.J. 763, 780-84 (1983). Kronman argues that where the promisor is barred from substituting damages for specific performance, and performance entails some ongoing personal cooperation with the other party or subjection to his personal supervision, the promisor's regret is likely to be more intense and its effects more serious, and "may pose a special threat to his integrity or self-respect." Id. at 783. In such cases, he suggests a mandatory cooling-off period. Id. at 795-96.

34 Studies have concluded that many birth mothers severely underestimate the emotional trauma resulting from giving up the child. See, e.g., Vicki C. Jackson, Baby $M$ and the Question of Parenthood, 76 Geo. L.J. 1811, 1820-21 (1988); Leverett Millen \& Samuel Roll, Solomon's Mothers: A Special Case of Pathological Bereavement, 55 Am. J. Orthopsychiatry $411,412-13$ (1985). Obviously we do not make all contracts void or voidable when there is asymmetric information. Sellers frequently know more about products than buyers, and yet the buyers' contracts will be enforced. See Phillip Nelson, Information and Consumer Behavior, $78 \mathrm{~J}$. Pol. Econ. 311 (1970). Neither party in longterm relational contracts, such as marriages, can know precisely what cohabiting-withcommitment will be like before the vows are taken. See Charles J. Goetz \& Robert E. Scott, Principles of Relational Contracts, 67 Va. L. Rev. 1089 (1981); Elizabeth S. Scott, Rational Decisionmaking about Marriage and Divorce, 76 Va. L. Rev. 9 (1990). We do not invalidate marriage contracts because of this surprise, even though only one party may have been married before. As Professors Becker, Landes and Michael have pointed out, the surprise of what marriage is really like may cause the parties to divorce, see Gary $\mathrm{S}$. Becker, Elisabeth M. Landes \& Robert T. Michael, An Economic Analysis of Marital Instability, $85 \mathrm{~J}$. Pol. Econ. 1141 (1977), but this is not recision; rather it is breach or bilateral termination.

35 See Loving v. Virginia, 388 U.S. 1, 12 (1967) ("Marriage is one of the "basic civil rights of man,' fundamental to our very existence and survival."); Griswold v. Connecticut, 381 
performance of non-financial terms will never be ordered. ${ }^{36}$ As my colleague Lloyd Cohen wrote elsewhere with respect to marriage, "the marital duties are to be performed im a certain spirit, and no court can succeed in forcing an unwilling spouse to perform marital duties im a spirit of love and devotion." 37 In surrogacy, knowing during pregnancy that specific enforcement is possible could inake the pregnancy a mightmare. ${ }^{38}$ The woman who has changed her mind after the apphicable statutory revocation period ${ }^{39}$ has every incentive to hate and resent the child she carries. She might try to extract additional money from the intended parents to guarantee that she will not engage in conduct that will harm "their" child-engaging in reckless activities such as sky-diving, drinking exces-

U.S. 479, 486 (1965) ("[Marriage] is an association that promotes a way of life, not causes; a harmony in living, not political faiths; a bilateral loyalty, not commercial or social projects. Yet it is an association for as noble a purpose as any involved in our prior decisions."); Maynard v. Hill, 125 U.S. 190, 211 (1888) ("[Marriage] is an institution, in the maintenance of which in its purity the public is deeply interested, for it is the foundation of the family and of society, without which there would be neither civilization nor progress."). Furthermore, as Professor Epstein noted, the presumption should be set "in favor of voluntary exchange" on the grounds that in the ordinary case such a presumption improves the life-prospects of both persons to the contract. Epstein, supra note 3, at 2314.

$36 \mathrm{Cf}$. Margaret F. Brinig \& June Carbone, The Reliance Interest in Marriage and Divorce, 62 Tul. L. Rev. 855, 870-72 (1988) (discussing the concept of damages and specific performance in terms of the reliance and expectations interests in marriage). For more general discussions of damages, including the remedy of specific performance, see Jim Leitzel, Reliance and Contract Breach, 52 Law \& Contemp. Probs. 87 (1989) (examining legal and economic approaches to the protection of the reliance interest); Steven Shavell, The Design of Contracts and Remedies for Breach, 99 Q.J. Econ. 121, 130-46 (1984) (discussing the relative desirability of various contract remedies).

37 Lloyd Cohen, Marriage, Divorce, and Quasi Rents; or, "I Gave Him the Best Years of My Life," 16 J. Legal Stud. 267, 300 (1987); see also Trebilcock \& Keshvani, supra note 18, at 584-85 (recommending a cooling-off period of 72 hours after birth in order to make "the two sides of the exchange more simultaneous" and confront the birth mother "with a more reasoned and informed choice"). But see Note, Rumpelstiltskin Revisited: The Inalienable Rights of Surrogate Mothers, 99 Harv. L. Rev. 1936, 1953-54 (1986) (arguing that the surrogate should not have the power to breach and pay damages because the father's rights to personhood are equivalent to those of the surrogate).

38 Carl Schneider states that "specific performance will often be impractical and even cruel." Schneider, supra note 6, at 128 . Maurice Suh recalls an horrific example in which a surrogate who originally agreed to provide her services free of charge began to demand payments during pregnancy, using the additional money to pay for alcohol and drugs as well as her legitimate expenses. The child was ultimately born with fetal alcohol syndrome. Suh, supra note 22 , at 360 n.17.

39 In Virginia, the statutory revocation period for court-approved surrogacy contracts is 180 days. Va. Code Ann. $\$ 20-161$ (B) (Michie 1995); accord Unif. Status of Children of Assisted Conception Act $\$ 7($ b), 9B U.L.A. 162 (Supp. 1994). 
sive amounts of alcohol or caffeine, dieting, or injecting drugs to numb the pam of her nine-inonth predicament. ${ }^{40}$

The information problein justifies at least some intervention into a free surrogacy market. The state might require counseling or provision of mental health follow-up services. It might allow the custoinary ten-day period after birth before consent is finally (i.e. specifically enforceably) given. ${ }^{41}$ It might simply change the contract from a "fully enforceable" agreement to one where the remedy is the more typical one of money damages. $^{42}$

According to economic analysis, contracts also become less than fully enforceable where there are substantial negative third-party effects. ${ }^{43}$ Although most contracts affect third parties, at least indirectly, sometimes the contracting parties inust buy off the affected outsiders. ${ }^{44}$ So long as the compensation takes place, ${ }^{45}$ the contract remains efficient and

40 Posner argues that there may be "extortion" by the surrogate where the contracts cannot be specifically enforced. Posner, supra note 17, at 422 . This extortion may involve threats to refuse to turn over the child or to behave irresponsibly during the pregnancy.

41 Virginia law provides for a 25-day waiting period in cases where the surrogacy arrangement is not judicially approved. See Va. Code Ann. $\$ 20-162$ (A)(3); see also Brinig, supra note 16 , at 566-73 (discussing state revocation statutes).

42 In this context, Professor Epstein notes:

[T] he suggestion about monetary compensation may be academic: the surrogate mother may not have the resources to pay any coinpensation, which would be difficult to determine in any event. And even if such compensation could be set and paid, it would leave the biological father and his wife far short of what they sought to achieve from this agreement.

Epstein, supra note 3, at 2337.

43 For example, Professor Epstein has written that the only sound justification for inalienability is "the practical control of externalities." Richard A. Epstein, Why Restrain Alienation?, 85 Colum. L. Rev. 970, 970 (1985). Such externalities are usually present when resources must be shared. Id. at 978-82. In this Symposium, he writes that "the legal response should be to ban or restructure those transactions whose negative third-party consequences outweigh the gains to the transacting parties. ... [when] gains and losses are measured by a compensation criterion." Epstein, supra note 3, at 2315; see also June R. Carbone, The Role of Contract Principles in Determining the Validity of Surrogacy Contracts, 28 Santa Clara L. Rev. 581, 590-97, 610 (1988) (discussing third-party interests and arguing in favor of enforcement so that genetic fathers can enter the agreements with confidence in the certainty of the outcoine).

44 In situations where third parties are bought off, the contract becomes Pareto-optimal. For discussions of Pareto optimality, see Jack Hirschleifer, Price Theory and Applications 496-97 (4th ed. 1988); Hal R. Varian, Microeconomic Analysis 203-06, 269 (2d ed. 1984).

45 At least the compensation occurs theoretically, according to Kaldor-Hicks optimality. See, e.g., P.R.G. Layard \& A.A. Walters, Microeconomic Theory 32 (1978); Varian, supra note 44, at 268-70. The original articles are Nicholas Kaldor, Welfare Propositions of Economics and Interpersonal Coinparisous of Utility, 49 Econ. J. 549 (1939); J.R. Hicks, The Valuation of the Social Income, 7 Economica 105 (1940). 
enforceable. When the costs to the third party or parties are too high, the contract may be prohibited criminally, ${ }^{46}$ enjoined, ${ }^{47}$ or just not enforced.

In the divorce setting, there are frequently third parties who are not part of the main action-the couple's children. They suffer substantial negative externalities when their parents separate, ${ }^{48}$ so much so that some states have made it more difficult for the parents to divorce. ${ }^{49} \mathrm{We}$ try to inake things easier for these children by allowing child support to approximate the standard of hiving they would have enjoyed if their par: ents had remained together. ${ }^{50}$ In some states, the court may order the divorcing parents to provide the children a college education, ${ }^{51}$ a right children with married parents cannot clainn.

Although any negatives flowing to the contracted-for child are probably outweighed by the benefits of existence, ${ }^{52}$ what are the benefits of the

46 This would include, for example, such conduct as drag-racing and playing "chicken." See, e.g., Jacobs v. State, 184 So.2d 711 (Fla. Ct. App. 1966). For a game theoretic explanation, see Charles J. Goetz, Cases and Materials on Law and Economics 15-18 (1984).

${ }^{47}$ This is the case in nuisance situations. See, e.g., Hart v. Wagner, 40 A.2d 47 (Md. 1944).

48 See E. Mavis Hetherington, Martha Cox \& Roger Cox, Effects of Divorce on Parents and Children, in Nontraditional Families: Parenting and Child Developinent 233 (Michael E. Lamb ed., 1982); E. Mavis Hetherington, Martha Cox \& Roger Cox, Long-Term Effects of Divorce and Remarriage on the Adjustment of Children, $24 \mathrm{~J}$. Am. Acad. Child Psychiatry 518 (1985); Judith S. Wallerstein, The Long-Term Effects of Divorce on Children: A Review, 30 J. Am. Acad. Child \& Adolescent Psychiatry 349 (1991). A less formal account is presented in Barbara D. Whitehead, Dan Quayle Was Right, Atlantic Monthly, Apr. 1993, at 47.

49 Current statutes continue to make divorce more difficult when there are children. In Virginia, the waiting period is six months for couples without children and twelve months for couples with thein. See Va. Code Ann. $\$ 20-91$ (Michie 1995). Some states require conciliation before granting divorces when there are children. See, e.g., Wisc. Stat. Ann. $\$ 767.25$ (West 1993); see also Scott, supra note 34 (discussing the effects of different legal regimes on decisions to divorce); Barbara D. Whitehead, A New Fannilism, Fam. Aff. 1, 5 (1992) (same).

50 See, e.g., Cole v. Cole, 409 A.2d 734 (Md. Ct. Spec. App. 1979); Conway v. Conway, 395 S.E.2d 464 (Va. Ct. App. 1990).

51 See, e.g., Kujawinski v. Kujawinski, 376 N.E.2d 1382 (Ill. 1978). Of course, money (and even higher education) does not buy happiness. The requirement that the noncustodial parent pay for college might, however, palliate the pain of divorce somewhat.

52 Cf. Zepeda v. Zepeda, 190 N.E.2d 849, 857-59 (Ill. App. Ct. 1963) (discussing the dangers of recognizing a cause of action for wrongful life); Berman v. Allan, 404 A.2d 8, 12 (N.J. 1979) (noting the belief in our society that life is more precious than non-life). But see Areen, supra note 1, at 1746-48 (noting that surrogacy increases the risk that the father and his spouse may wish to reject less-than-perfect infants as "damaged goods"). I recognize that Professor Epstein has written elsewhere that "[t]he current view sees externalities everywhere. In effect it isolates one negative consequence of any action on third parties and uses it to justify the prohibition of that action, no matter how large the 


\section{contracted-for child's existence to the surrogate's other children? ${ }^{53}$}

One of the particularly maternalistic things family law does is to place children first despite their parents' attempts to ignore their children's interests in favor of their own. ${ }^{54}$ In our fascination with the adults involved in these surrogacy arrangeinents, however, we seem to have forgotten soine players. Whether we ought to coinpensate the children directly, offer them family therapy, or just question whether surrogacy is a good idea, I leave to your imagination. ${ }^{55}$

gains for others." Richard A. Epstein, The Harm Principle-And How It Grew, Address at the Canadian Law and Economics Association Annual Meeting 35 (September 30, 1994). I agree with him that the "full range of consequences has to be grasped and evaluated, comprehensively and not selectively, not case by case, but by broad categories of cases." Id.

53 There is a kind of double-bind here. If the surrogate has never had children, there is a greater information problem. See Strasser, supra note 1, at 143-44. If she has children, they may be deeply and permanently injured by the surrogacy contract. The compensation paid the surrogate is surely not enough to justify this harm. New Hampshire, for example, requires a prior live birth in order for a woman to qualify as a surrogate. See N.H. Rev. Stat. Ann. § 168-B:17(V) (1994); see also Va. Code Ann. \$20-160B(6) (Michie 1995) (providing that a prior pregnancy is one qualification, inter alia, required for the court to discharge otherwise mandatory guardian ad litem for the prospective child and attorney for the surrogate).

54 For example, adoption and custody matters are always conducted in the "best interests of the child." Parents cannot contract out of their duty to pay child support. Cf. Richardson v. Moore, 229 S.E.2d 864 (Va. 1976) (holding that wife's passive acquiescence did not justify reduction in former husband's support payments even though 25 years had passed); Department of Social Servs. v. Hogge, 431 S.E.2d 656 (Va. Ct. App. 1993) (holding that father could not reduce support payments in retaliation for mother's denial of visitation rights). Nor can they fail to provide medical care in life-threatening situations, even if their religion forbids it. See, e.g., People ex rel. D.L.E., 645 P.2d 271 (Colo. 1982); Hermanson v. State, 604 So.2d 775 (Fla. 1992); In re Custody of a Minor, 379 N.E.2d 1053 (Mass. 1978). They are expected to protect their children because "natural bonds of affection lead parents to act in the best interests of their children." Parham v. J.R., 442 U.S. 584, 602 (1979). They usually cannot make binding custody determinations either. See Schneider, supra note 6, at 127; Trebilcock \& Keshvani, supra note 18, at 577. As Judge Wilentz remarked in In re Baby M, 537 A.2d 1227 (N.J. 1988): "The contract's basic premise, that the natural parents can decide in advance of birth which one is to have custody of the child, bears no relationship to the settled law that the child's best interests shall determine custody." Id. at 1246.

55 Compare Posner, supra note 17, at 423 (concluding that "the psychic costs, if any, to those children must be balanced against the possible gains to them from their mother's having a higher incoine, as well as against the gains to the father of the surrogacy child, to his wife, and to the child") with Michelle Harrison, Psychological Ramifications of "Surrogate" Motherhood, in Psychiatric Aspects of Reproductive Technology 97, 103-05 (Nada L. Stotland ed., 1990) (describing the severe psychological impact of surrogate motherhood on the surrogate mother's other children). 
Finally, we come to iny last problem, the paid agencies. ${ }^{56}$ In order to describe the law-and-economics paradigm, we inust look a bit inore closely at the market involved. The adoption market, of which surrogacy is a subset, is characterized by extremely inelastic demand and very restricted supply. ${ }^{57}$ The supply of adoptable babies is short primarily because of effective contraception, elective abortions, and the growing relaxation of the stigma attached to unwed parenting, mcluding some subsidization of unwed parenting through public assistance. ${ }^{58}$

Middlemen, because they can reduce the transaction costs associated with the search, are generally highly desirable. ${ }^{59}$ But where there are easy ways of obtaining information and inaking efficient trades, ${ }^{60}$ one

56 Professor Epstein dismisses coordination problems as an issue, stating that " $[t]$ hese transactions, which involve a small number of parties, can be facilitated by a group of eager intermediaries." Epstein, supra note 3, at 2316.

57 See Brinig, supra note 16, at 554; Prichard, supra note 8, at 342-43. Richard Posner has suggested that critics of surrogate motherhood ought to support the reform of adoption law. See Posner, supra note 17, at 422.

58 See Cohen, Posnerism, supra note 5, at 109-10.

59 See, e.g., Armen Alchian \& William R. Allen, Exchange \& Production: Competition, Coordination, \& Control 48-50 (3d ed. 1983). In fact, Posner argues that middlemen are desirable because the "person who does something about an imbalance between demand and supply should not be blamed just because his motivation is financial. The idea that middlemen are parasites refiects the kind of primitive iguorance of economics that we expect to encounter in the Soviet Union, not in New Jersey." Posner, supra note 17, at 427; accord Posner, Ethics and Economics, supra note 8, at 30 ("The court's hostility to middlemen is primitive. They provide an essential function in markets.").

60 See, e.g., R.H. Coase, The Firm, the Market, and the Law 38 n.18 (1988) (citing Nicholas Kaldor, A Classifactory Note on the Determinateness of Equilibrium, Rev. of Econ. Stud., Feb. 1934, at 123) (describing what was later called the Kaldor-Hicks equilibrium, where the gains to the contracting parties are sufficient to pay off third parties who might be harmed). In a more recent example, Alchian \& Allen's discussion begins with the statement that "we know there are substantial costs of finding trade possibilities, of assessing the true characteristics or qualities of goods, and of negotiating exchange contracts and arranging for such legal protections as warranties." Alchian \& Allen, supra note 59 , at 48 . Independent adoptions, which mirror surrogacy, constitute the majority of adoptions in California and Texas. See Cohen, Posnerism, supra note 5, at 130 (citing the Nat'l Comm. for Adoption, Adoption Factbook: United States Data, Issues, Regulations and Resources 14 (1985) [hereinafter Factbook]). The Factbook contains examples of ads taken from various newspapers. See Factbook, supra, at 122. The Factbook further provides a very substantial list of support organizations for adoptive parents, see id. at 22339 (listing, for example, 12 such groups in Virginia alone), as well as a list of state adoption exchanges and photo listing books, see id. at 230-31 (providing information for 38 states, including Virginia). Professor Epstein worries about the "extensive selection process to find those women who are most likely to be able to deliver a healthy baby at term. Similarly, potential surrogate mothers, like parents placing infants for adoption, want to select suitable parents for the babies to whom they give birth." Epstein, supra note 3, at 2317. 
would expect that the market would eliminate brokers because they are not eliminating costs in the system. ${ }^{61}$ However, there are several features of the surrogacy market that explain the existence of middlemen. Two of these involve the incentives that exist for brokers to enter the inarket. First, because there is an extremely inelastic demand for the "good" in question, the middleman may extract the "consumer surplus" from one or both parties to the transaction. ${ }^{62}$ To do so, the middleman may engage in substantial rent-seeking through public ${ }^{63}$ or private ${ }^{64}$ mechanisms. The second unusual feature is the legal uncertainty that has surrounded surro-

61 This would occur even more speedily if, as I will allege, the brokers are actually encouraging inefficient contracting. See infra notes 66-72 and accompanying text.

62 For example, in the debate on the British surrogacy legislation, which ultimately prohibited commercial surrogate contracts, one speaker noted that "the distress . . . of infertile couples who are anxious to have a child should not be exploited [by commercial agencies] for gain," 464 Parl. Deb., H.L. (5th ser.) 1521 (1985) (remarks of Lord PrysDavies). As we shall see in a moment, this may be exaction of a higher finder's fee from the transacting couple, who would otherwise pay some larger incremental, but smaller total, amount to the surrogate. For a discussion of the agency costs problem, see Trebilcock \& Keshvani, supra note 18, at 587 (arguing that agencies that are commissioned and paid by the adoptive parents are unlikely to be equally attentive to the interests of the birth mother). For a discussion of "rent extraction" in the marriage context, see Cohen, supra note 37, at 284-89. Professor Epstein sees the remedy in terms of the "norms of disclosure. . . . The terms and conditions of the relationship can be fully explained; independent counselors and advisers can be brought in to explain the situation to the potential surrogate." Epstein, supra note 3, at 2318. He suggests that the need for such disclosure "should be quite apparent to contracting parties, making it quite dangerous to pile on additional restrictions." Id. The question in the end becomes who provides the disclosure and explains the terms and conditions. I wonder whether commercial agencies should be involved in the process; legislatures uniformly think not. See Marsha Garrison, Surrogate Parenting: What Should Legislatures Do?, 22 Fam. L.Q. 149, 154 n.24 (1988).

63 This might be evidenced in the effort to get favorable surrogacy statutes enacted, see, e.g., Jana B. Singer, The Privatization of Family Law, 1992 Wis. L. Rev. 1443, 1494-95 (discussing state legislative debates over surrogacy and the failed attempt of the Family Law Section of the ABA to get a very permissive surrogacy statute endorsed by the House of Delegates), or, more likely, to gain some sort of license or monopoly protection for the offering of surrogate matching services. The concept of rent-seeking was coined in an article by Anne O. Krueger, The Political Economy of the Rent-Seeking Society, 64 Am. Econ. Rev. 291 (1974). James Buchanan suggests that in the regulatory setting, there may be three types of wasteful rent-seeking expenditures: the efforts and expenditures of the potential recipients of the monopoly, the efforts of government officials to obtain or to react to the expenditures of the potential recipients, and third-party distortions induced by the monopoly itself or the government as a consequence of the rent-seeking activity. See James M. Buchanan, Rent Seeking and Profit Seeking, in Toward a Theory of the RentSeeking Society 3, 12-14 (James M. Buchanan, Robert D. Tollison \& Gordon Tullock eds., 1980).

64 For example, there is advertising. See Donald McCloskey, One-Fourth of GNP is Persuasion, Address at the Annual Meeting of the Southern Economics Association (Nov. 5 , 1994). Surrogate agencies "solicit potential surrogates through advertisements in 
gacy. Because in most states the law of surrogacy is unsettled, lawyers can offer what looks like a guarantee of greater success, a "watertight" contract, which may induce couples and surrogates to go through the broker in making surrogacy arrangements. This, of course, may be a transitory phenomenon as more legislatures react to the surrogacy question. Ideally, once the law is settled (even if it is law that says that money cannot be exchanged or contracts cannot be specifically enforced), this apparent (and illusory) insurance function will disappear. The third feature is that any "mistakes" will reveal the relevant information to prospective contracting parties only at the expense of existing children. ${ }^{65}$ Should surrogate brokering be found illegal in the context of contract litigation, as opposed to legislation or declaratory relief, a pregnancy will already have begun. If the agency is sued after the contract fails, the losing party and (indirectly) the child will be affected.

As noted previously, these profit agencies may also act to reduce the beneficial fiow of information between contracting parties, causing some "inefficient contracting." ${ }^{6}$ Although state legislatures may be moved by reasons that do not include econonnic efficiency, it is surprising that com-

newspapers and flyers; they also use radio and television appearances as recruiting devices." Singer, supra note 63, at 1492.

65 This problem is a bit like that confronting "equality" feminists who wish to eliminate alimony as a means to encourage labor force participation by women. The problem is that human beings, in this case housewives who married with a different set of reasonable expectations, have to bear the cost of producing the desired result for the current crop of young women. See Margaret F. Brinig, The Law and Economics of No-Fault Divorce-A Review of No-Fault Divorce: What Went Wrong?, 26 Fam. L.Q. 453, 455 n.10 (1993) (book review).

In this context, as a British legislator noted, "[t]he law of the market place should have no part in a society and a legal system which treat the welfare of the child as the first consideration," 464 Parl. Deb., H.L. (5th ser.) 1523 (1985) (remarks of Lord Meston), so that while the child's welfare comes first in adoption, it often comes last in surrogacy arrangements if they are based purely on contract principles.

66 This has certainly occurred in the traditional adoption context, as is evidenced by "wrongful adoption" cases. See Roe v. Catholic Charities, 588 N.E.2d 354 (IIl. App. Ct. 1992); Juman v. Louise Wise Servs., 608 N.Y.S.2d 612 (Sup. Ct. 1994), aff'd, 520 N.Y.S.2d 371 (App. Div. 1995); Gibbs v. Ernst, 647 A.2d 882 (Pa. 1994). J. Robert S. Prichard suggests that "there may be some significant information imperfections in the proposed market" for babies. Prichard, supra note 8, at 348; see also Areen, supra note 1, at 1755 (describing adoption agency's failure to disclose reservations about surrogate's suitability to surrogate or to potential adoptive parents); Brian J. Carney, Note, Where Do the Children Go?-Surrogate Mother Contracts and the Best Interests of the Child, 22 Suffolk U. L. Rev. 1187, 1191-92 nn.29-31 (1988) (questioning whether surrogacy agencies provide sufficient safeguards). See generally Rebecca Powers \& Sheila G. Belloli, The Baby Business, Detroit News, Sept. 17, 1989, at 1A (describing the human and financial cost of broken surrogacy contracts and fraudulent brokers). 
mercial "baby brokering" is almost universally illegal. ${ }^{67}$ In our jurisdictional market, if these middlemen were a good idea, presumably some state would have experimented with them. ${ }^{68}$

If surrogacy is permitted, as I think it should be to discourage formation of a surrogate black market, ${ }^{69}$ the state need not encourage baby brokerage. In surrogacy, the finder is frequently paid as much as the surrogate. ${ }^{70}$.It would be preferable either for the surrogate to reap this consumer surplus ${ }^{71}$ or for the intended parents to be made still happier because they need not pay a surrogate broker fee. ${ }^{72}$ The brokers should

${ }^{67}$ For a list of the state statutes, see Barbara L. Atwell, Surrogacy and Adoption: A Case of Incompatibility, 20 Colum. Hum. Rts. L. Rev. 1, 28 n.110 (1988).

68 For important studies of jurisdictional competition in other contexts, see Dennis C. Mueller, Public Choice II 154-70 (1989); Roberta Romano, The Genius of American Corporate Law (1993); Bernard S. Black, Is Corporate Law Trivial?: A Political and Economic Analysis, 84 Nw. U. L. Rev. 542 (1990). The classic study in this field is Charles M. Tiebout, A Pure Theory of Local Expenditures, 64 J. Pol. Econ. 416 (1956).

${ }^{69}$ See, e.g., Garrison, supra note 62 , at 155 (arguing that criminalizing surrogacy is not likely to have a great deterrent effect, as triers of fact "are unlikely to take surrogate parenting arrangements more seriously than black market adoptions"); Elisabeth $M$. Landes \& Richard A. Posner, The Economics of the Baby Shortage, 7 J. Logal Stud. 323, 338 (1978) (asserting that much of the profit in black markets would be captured by the intermediary); Prichard, supra note 8, at 343 (reporting increasing black market activity characterized by very high prices for newborns - as much as $\$ 40,000$ - but continued interest on the part of childless couples). New York is one state that has completely outlawed commercial surrogacy contracts. See N.Y. Dom. Rel. Law \$\$ 121-124 (McKinney 1986); see also Mich. Comp. Laws Ann. $\$ 722.859$ (West 1992) (outlawing surrogacy contracts); Utah Code Ann. \& 76-7-204 (Michie 1995) (prohibiting surrogacy contracts and stating that the surrogate mother's husband is the legal father of children born in surrogacy).

70 See Andrews \& Douglass, supra note 5, at 635 ("The couple who contracts with a paid surrogate will spend at least $\$ 25,000$ : approximately $\$ 10,000$ for the surrogate mother, $\$ 10,000$ for the agency that arranges the procedure, as well as related miscellaneous costs.").

71 See id. at 672. Additional compensation paid incrementally throughout the contracting period should decrease incentives to renege.

72 Richard Posner suggests that lack of enforcement of the surrogacy contracts should provide incentives for the contracting couple to screen potential surrogates more carefully. See Posner, supra note 17, at 422 . But he concludes that such screening "is bound to be costly and of limited efficacy," reducing the gains to both sides of the transaction. Id. at 422-23. One question is whether private agencies can do this screening better.

Even assuming that they can, given the possibility that the brokers might cause more problems by "passing off" less than perfect surrogates, making it illegal to pay brokers might give them appropriate incentives to be careful. If the contract succeeds, so that both sides are happy with the broker's services, there is no problem. If the baby is "defective" because the mother has problems the surrogate did not disclose, including genetic illnesses, bad habits, or an attitude of ambivalence about whether to complete the contract, the father and his wife could sue the agency. Damages would not undo the harm done, since 
not extract this profit. Lawyers may be needed to handle the adoptions by the intended mothers, but should only charge their (much lower) custoinary fee for this service. ${ }^{73}$

I have told you that I am not a friend of surrogacy contracts, ${ }^{74}$ even though I agree with many if not most of Richard Epstein's assumptions about contractual enforcenent. ${ }^{75}$ I hope I have demonstrated how you can reach the same conclusions from a family-law and a law-and-economics perspective, although I realize that few will be convinced of anything in this debate. Although many couples have purportedly been made happy by surrogacy, ${ }^{76}$ and very few have publicly complained, ${ }^{77} \mathrm{I}$ do not see a movement toward specifically enforcing contracts for prostitution, or, far closer to the point, marriage or adoption. ${ }^{78}$ To paraphrase

the baby cannot be "returned" as defective, but a threat to reveal the broker's acceptance of illegal compensation might be enough to deter the bad conduct from happening in the first place. Cf. Richard A. Epstein, Blackmail, Inc., 50 U. Chi. L. Rev. 553 (1983):

As a moral matter, therefore, blackmail is criminal because of its necessary tendency to induce deception and other wrongs.... [I]f blackmail were legal we should expect Blackmail, Inc. to emerge to service the available market. Making blackmail criminal has the very powerful effect of shutting down Blackmail, Inc. even before it can open its doors.

Id. at $565-66$.

73 State agencies or even parents' organizations could provide a standard form contract. The terms might include those specified in the Virginia and New Hampshire surrogacy statutes. See supra note 29.

74 Unlike Professor Epstein, I do not believe that surrogate contracts should be "a source of hope and affirmation." Epstein, supra note 3, at 2340.

75 I also agree with Richard Posner's analysis: "Because surrogacy is so much less attractive to the father and wife when it is not enforceable, they will not be willing to pay nearly as much as they would if it were enforceable-so the surrogate is hurt." Posner, Ethics and Economics, supra note 8, at 23.

${ }^{76}$ Lori Andrews and Lisa Douglass state that "[s]ince the late 1970s, an estimated four thousand children have been born to surrogate mothers." See Andrews \& Douglass, supra note 5, at 670 (citing Martin Kasindorf, And Baby Makes Four: Johnson v. Calvert Illustrates Just About Everything That Can Go Wrong in Surrogate Births, L.A. Tinies Mag., Jan. 20, 1991, at 10); see also Andrews, supra note 5, at 74 (stating that only one percent of surrogates change their minds).

77 As Lori Andrews and Lisa Douglass have noted, only a very low percentage of the surrogates have voiced complaints. Andrews \& Douglass, supra note 5, at 678.

78 As William Joseph Wagner writes: "The criteria of enforcement are voluntariness, or consent, and cooperation in the form of business or commercial exchange. Freedom of individual action requires a corresponding nonenforcement of involuntary duties of kinship or social convention, with the exception of certain carefully defined family duties." William J. Wagner, The Contractual Reallocation of Procreative Resources and Parental Rights: The Natural Endowment Critique, 41 Case W. Res. L. Rev. 1, 15 (1990). Wagner argues for damages as opposed to specific performance. Id. at 48 \& n.201 (citing Edward Yorio, In Defense of Money Damages for Breach of Contract, 82 Colum. L. Rev. 1365, 1385-86 (1982)). 


\section{Professor Epstein, what is so special about surrogacy? ${ }^{79}$}

Surrogacy, then, may be a kind of "demerit good," one we-or at least I-view instinctively as harmful regardless of what the individuals participating in the transaction decide. Society need not prohibit these goods, but may merely tax or otherwise regulate them to make them less attractive. ${ }^{80}$ This, of course, is a return to the maternalism with which we

Another way of thinking about this problem involves reexamining the classic case for specific performance: the uniqueness of the goods in question. Contracts are typically enforced specifically when they involve such matters as purchasing homes or customized sports cars. See, e.g., Sedmak v. Charlie's Chevrolet, Inc., 622 S.W.2d 694 (Mo. Ct. App. 1981) (awarding specific performance for breach of contract to sell an automobile); Lucy v. Zehmer, 84 S.E.2d 516 (Va. 1954) (awarding specific performance for breach of contract to sell land). See generally Alan Schwartz, The Case for Specific Performance, 89 Yale L.J. 271, 274-78 (1979) (discussing the contract remedy goal of compensation). Although the regret may be substantial and the deal may be highly loaded with sentiment, in the end the court is dealing with things. In the genre of surrogacy cases, specific enforcement is problematic for all the reasons discussed previously, most of which involve the fact that people, not things, are going to be hurt no matter what the court does. Or, as Professors Goetz and Scott argue, if the relevant issue is which party has the advantage in acquiring substitute goods in an imperfect market, see Charles J. Goetz \& Robert E. Scott, The Mitigation Principle: Toward a General Theory of Contractual Obligation, 69 Va. L. Rev. 967,988 (1983), the breach might be a "cry for help" by the surrogate. The surrogate might be requesting that the couple mitigate her losses.

79 In other words, if, as Professor Epstein noted, it is important to have a "wellarticulated system of property rights," Epstein, supra note 3, at 2310. I would assign the property right in this case to the surrogate mother.

As two of the law review editors attending the Symposium mentioned, lack of specific performance does pose problems for those children whose mothers successfully change their minds, because it plunges them into a contested custody case like that in Baby $M$. Although that case was no doubt extremely hard on the child in question, however, there are some other considerations. One is that the number of such children has been, and will continue to be, small, especially in comparison to the number of siblings affected by surrogacy. The second is that these few children are wanted children, with "too many parents" or would-be parents. Cf. Watson v. Shepard, 229 S.E.2d 897, 902 (Va. 1976) (denying adoption by paternal aunt and her husband, who were separated and might divorce and remarry, although custody was not returned to the natural mother). This is a different problem from that faced by the children of adoption and most children of surrogate contracts, who discover that their natural parents were willing to part with them. A final note is that many children born as the result of surrogate contracts still enjoy celebrity status, and may have some psychological problems in even the most successful cases. It is too soon to be certain.

80 See Richard A. Posner, Taxation by Regulation, 2 Bell J. Econ. \& Mgmt. Sci. 22 (1971). For an application of this principle, see Timothy J. Brennan, Economic Efficiency and Broadcast Content Regulation, 35 Fed. Com. L.J. 117, 134 (1983) (discussing content regulation of offensive material). I thank Lloyd Cohen for this useful analogy. 
began, for it is an outsider's judgment that surrogacy is inherently suspect that labels surrogacy a "demerit good."

81 In Avery Katz's terminology, I am rejecting an extreme view of normative individualism here. "One of these might be called subjective utilitarianism; it is that individuals are ordinarily the best (and in extreme formulations, the only) judges of what is in their interests." Avery Katz, Positivism and the Separation of Law and Economics 6 (1994) (unpublished manuscript, on file with the Virginia Law Review Association). Or, as Milton Regan puts it, I am elimmating from this context concerns driven by what he calls "the acontextual self." "Rather than being shaped by any context, the contractual actor creates her own contexts. Inequalities of bargaining power, for instance, are merely the result of prior individual choices, rather than restraints on choice." Milton C. Regan, Family Law and the Pursuit of Intimacy 91 (1993). 
